\title{
GAB2 wt Allele
}

National Cancer Institute

\section{Source}

National Cancer Institute. GAB2 wt Allele. NCI Thesaurus. Code C52386.

Human GAB2 wild-type allele is located in the vicinity of $11 \mathrm{q} 14.1$ and is approximately 202 $\mathrm{kb}$ in length. This allele, which encodes GRB2-associated-binding protein 2, plays a role in hematopoetic cell receptor signal potentiation. 